\title{
ENSINO E APRENDIZAGEM DE HISTÓRIA: TRADICIONAL X TECNOLOGIA
}

\section{Juliana Gonçalves da Silva ${ }^{1}$ \\ Nelma Furtado da Costa ${ }^{2}$ \\ Ana Enedi Prince ${ }^{3}$}

Resumo: Esse artigo explana a realidade da era tecnológica em concorrência com os métodos tradicionais de ensino petrificados e inibidores do processo de ensino e aprendizagem. Considerando que o conhecimento ocorre a partir das relações do individuo com o mundo em que ele vive, o ensino precisa partir da atualidade, sendo o educador o mediador que deverá e poderá transformar a escola, em um local agregador entre as informações prévias do educando e o conteúdo administrado. A educação brasileira foi voltada para atender as necessidades políticas de cada período, com pouca preocupação para o enriquecimento cultural da sociedade como um todo, ou seja, o foco do ensino não estava centrado no aluno. Visando a não repetição desse equívoco é que se faz relevantes as pesquisas das mudanças da sociedade e a função social da escola, transformando essa última como agente construtor do conhecimento. Palavras-chave: Recursos didáticos; História; Ensino; Aprendizagem.

\footnotetext{
1 História/UNIVAP Campus Platanus, Brasil. E-mail: ju_3578@hotmail.com.

2 História/UNIVAP, Campus Platanus, Brasil. E-mail: nelmafurtado_costa@hotmail.com.

${ }^{3}$ História/UNIVAP, Campus Platanus, Brasil. E-mail: prince@univap.br.
} 